Article

\title{
When and How Does Sustainable HRM Improve Customer Orientation of Frontline Employees? Satisfaction, Empowerment, and Communication
}

\author{
Youngsam Cho ${ }^{1}$ (D) and Yongduk Choi ${ }^{2, *(D)}$ \\ 1 College of Business, Gyeongsang National University, BERI, Jinju-daero 501, Jinju 52828, Korea; \\ yscho@gnu.ac.kr \\ 2 College of Business, Chonnam National University, Yongbong-ro 77, Buk-gu, Gwangju 61186, Korea \\ * Correspondence: ydchoi@jnu.ac.kr; Tel.: +82-62-530-1471
}

check for

updates

Citation: Cho, Y.; Choi, Y. When and How Does Sustainable HRM Improve Customer Orientation of Frontline

Employees? Satisfaction,

Empowerment, and Communication. Sustainability 2021, 13, 3693. https:// doi.org/10.3390/su13073693

Academic Editors: Huseyin Arasli, Trude Furunes and Hasan

Evrim Arici

Received: 25 February 2021

Accepted: 23 March 2021

Published: 26 March 2021

Publisher's Note: MDPI stays neutral with regard to jurisdictional claims in published maps and institutional affiliations.

Copyright: (c) 2021 by the authors. Licensee MDPI, Basel, Switzerland. This article is an open access article distributed under the terms and conditions of the Creative Commons Attribution (CC BY) license (https:/ / creativecommons.org/licenses/by/ $4.0 /)$.

\begin{abstract}
This study investigated the relationship between sustainable human resource management (HRM) practices, employee satisfaction, and customer orientation of frontline employees (FLEs) in the hotel industry from the perspective of internal marketing. Specifically, the study focused on three facets of sustainable HRM practices (i.e., training, reward, and benefit) as well as organizational empowerment and communication as FLE-supportive contexts. Although some studies have examined the relationship between HRM practices and customer orientation, they overlooked the importance of service context in facilitating FLE customer orientation. Thus, this study developed a comprehensive framework based on social exchange theory and self-determination theory. The results show that all three facets of the sustainable HRM practices were positively related to FLEs' satisfaction. FLEs' satisfaction was also positively related to their customer orientation. Furthermore, both organizational empowerment and communication moderated the relationship between FLEs' satisfaction and customer orientation, which showed a positive relationship only when FLEs perceived high organizational empowerment or communication. The research findings provide beneficial theoretical and practical implications.
\end{abstract}

Keywords: sustainable HRM; employee satisfaction; customer orientation; organizational empowerment; organizational communication

\section{Introduction}

The tourism and hospitality industry is one of the fastest growing and developing industries in the world [1]. Over the past half century, it has been continually expanding and diversifying as online and offline boundaries among countries have been torn down. The World Tourism Organization (UNWTO) reported that the development of the tourism industry has created various jobs and opportunities, eventually leading to economic recovery. In addition, according to the Korea Tourism Organization (KTO), the number of foreign tourists in South Korea has doubled since 2010 to about 17 million in 2019. In line with this trend, the number and sales of tourist accommodation businesses increased steadily from 2010 to 2017. In this study, we focused on the hotel industry, including tourist, business, and luxury hotels. The hotel industry should pay particular attention to customer service. Customers' satisfaction with hotel service is directly related to the success and survival of the hotel. Unlike the manufacturing industry, which produces goods, frontline employees (FLEs) play a considerably important role in customer satisfaction in the service or hotel industry [2]. Although the prices and facilities of a hotel are important, it is customers' feelings and experiences for the FLEs that induce customers to revisit and pass on favorable reviews through word of mouth. That is, they serve as the face of the hotel in the eyes of the guests. FLEs are valuable resources who build new customers and maintain extant customers by providing deep satisfaction for them through service experiences [3]. 
Previous literature has found that customer-oriented FLEs deliver better service quality [4] and improve customer satisfaction and retention compared to those who are not customer oriented [5]. According to Rucci et al.'s [6] study, 40\% to $80 \%$ of customer satisfaction depends on FLEs. Thus, customer-oriented FLEs can create a sustainable competitive advantage in the tourism and hospitality industry.

However, with the recent growth and development of the service industry, customers who had higher expectations for service were beginning to demand more and more from FLEs $[7,8]$. Their complicated needs and wants caused greater stress and depression for FLEs, leading to negative consequences, such as counterproductive behaviors, absenteeism, and turnover of FLEs, and serious losses for organization [9]. Several studies have also reported that roughly $20 \%$ of FLEs experienced demoralization due to a lack of intrinsic motivation, causing more than $15 \%$ to leave their jobs $[10,11]$. Thus, the objective of this study is to investigate the antecedents and context improving FLEs' customer orientation. When and how can service organizations improve FLEs' customer orientation? In this study, we approached this question from the perspective of internal marketing, which is considerably useful but relatively overlooked in Asian countries [8]. Heskett et al. [12] found that a $5 \%$ increase in employee satisfaction led to a $10.3 \%$ increase in customer satisfaction, which led to a $0.5 \%$ increase in revenue in a case study of a department store. Overall, FLEs' customer orientation should be preceded by their satisfaction, and customer orientation may enable customer satisfaction and the sustainable growth of the service organization.

From the perspective of internal marketing, we considered human resource management (HRM) practices as the most influential antecedents for employee satisfaction. In particular, we focused on sustainable HRM practices, described as the "adoption of HRM strategies and practices that enable the achievement of financial, social, and ecological goals, with an impact inside and outside of the organization and over a long-term time horizon while controlling for unintended side effects and negative feedback" [13]. Sustainable HRM focuses on creating competitive advantages for organizations by regenerating and developing human resources [14,15]. Based on the notion of sustainable HRM, we decided to adopt the three facets of training, reward, and benefit [16]. Social exchange theory could also be valuable for explaining the relationship between employees' satisfaction and their customer orientation. According to this theory, employees who perceive beneficial supports from their organization are likely to actively contribute in terms of a reciprocal attitude or behavior [17]. In this study, we also emphasized organizational empowerment and organizational communication as FLE-supportive contexts. FLEs should promptly and appropriately respond to customers' demands and complaints at the service encounter themselves. Even if satisfied FLEs benefit from sustainable HRM practices, it is difficult to commit to customer orientation if they do not have discretion for decision making and helpful information, leading to unexpected service situations through organizational empowerment and communication. Self-determination theory highlights the importance of autonomy and relatedness for improving employee motivation [18]. We next discuss our conceptual framework.

\section{Theoretical Background and Hypothesis Development}

\subsection{Perspective of Internal Marketing}

Internal marketing is regarded as the touchpoint between marketing and organization theories. Berry [19] first introduced internal marketing as a new perspective, viewing employees as internal customers for whom the organization should satisfy their needs and wants. He argued that organizations can archive the ultimate goals of customer satisfaction and revenue growth by satisfying their primary customers-namely, employees. In other words, the perspective of internal marketing considers the organization as an internal market. Although there has been no distinct consensus on the definition of internal marketing, the concept has evolved through three phases: initial, service, and holistic models. The initial model explained that organizations should pursue customer satisfaction 
by applying marketing techniques to employees' job design [19]. The service model emphasized satisfying employees in order to improve customer satisfaction [20]. In the more recent third phase, the holistic model focused on employee motivation, organizational empowerment, and interdepartmental cooperation, as well as employee satisfaction, to ensure customer satisfaction [21]. These various factors affecting employee or customer satisfaction have been included in the marketing mix or HRM. The two terms differ, but they in fact involve identical factors. Studies from the existing literature have shown that research approaches from the perspective of internal marketing have mainly focused on FLEs working in the service industry, due to its nature [21,22]. In other words, they examined the effects of marketing mix or HRM on customer-related outcomes, including customer orientation, customer-oriented behavior, and customer satisfaction through employee satisfaction. Thus, the perspective of internal marketing is appropriate for this study focusing on customer orientation of FLEs in the hotel industry.

\subsubsection{Sustainable HRM and Employee Satisfaction}

HRM includes a series of organizational processes for managing human resources, entailing recruitment, selection, job design, training, career development, performance appraisal, reward, benefit, and retirement. Unlike the traditional view of HRM, recent scholars have pointed out the importance of sustainable HRM as a new concept, responding to rapid changes in social needs and business environments. The goal of sustainable HRM is regenerating and developing social, economic, and human resources that contribute to organizations' sustainable competitive advantage [14,15]. Mariappanadar [16] also argued that sustainable HRM enables employees to sustain their health and well-being. Drawing upon this context, we used the motivation-enhancing bundle of HRM practices in this study. The scope of this bundle of HRM practices varies widely, but we decided to adopt three common practices - training, reward, and benefit [16] — for two reasons. First, the two most important interests of modern employees are self-development in a long-term perspective and (non-)monetary compensation from the organization, which can ensure the employees' job security and well-being. Second, organizations need skilled employees and should attract and retain such talented employees to gain sustainability in the fierce industrial competition. Therefore, training, reward, and benefit, as the three facets of sustainable HRM practices, are important for employee satisfaction and organizational survival.

Training refers to satisfying employees' needs for competence by acquiring new knowledge, skills, and experiences [23]. It can also increase employees' relatedness satisfaction by stimulating collaboration with organizational members through the team-building opportunities of role-play activities. In particular, employees perceive a favorable signal that the organization values and invests in them, building a long-term employment relationship [24]. Furthermore, well-trained or competent employees have a greater chance of promotion in organizations and higher employability in the job market. Thus, training is directly related to self-development and career development. Compensation refers to a comprehensive outcome that employees consider valuable. It is given from the organization in exchange for employees' effort and contribution. In this study, we divided the compensation for the organizational employees into two categories: reward and benefit. Reward refers to financial compensation, which includes pay, incentives, bonuses, and promotions based on performance appraisal. The equity model explains that employees gain satisfaction by comparing their input and output ratio [25]. According to the discrepancy model, a comparison of current and ideal job conditions, like rewards, determines employees' satisfaction [26]. Thus, job reward based on a proper and fair system is a major determinant leading to employee satisfaction. Arasli et al. [27] found that training and reward had a positive effect on service employees' commitment by improving their work engagement. Finally, benefit means fringe or social support, other than regular pay, that is provided to employees and their families for the purpose of improving their well-being. It is non-financial compensation for all employees, regardless of seniority or performance, and is provided to them in various ways (e.g., use of facilities, paid vacation, nurturing 
support, and other services). Prior studies have found that investing in a benefit system reduced employees' turnover rates [28]. Furthermore, a benefit has the characteristic of unconditional collective compensation, which facilitates building a cooperative organizational climate between management and employees [29]. Thus, benefit would be effective in satisfying and retaining employees. Based on this discussion, we hypothesized that:

H1. Sustainable HRM (H1a. Training, H1b. Reward, H1c. Benefit) is positively related to employee satisfaction.

\subsubsection{Employee Satisfaction and Customer Orientation}

Customer orientation indicates an inclination or tendency of employees to meet the customers' needs and wants in an on-the job context. This concept was introduced by Saxe and Weitz [30] as a marketing concept at the individual employee level. Extant literature found that this orientation had a positive relationship with customer outcomes, such as satisfaction and loyalty. In addition, Brady and Cronin [31] confirmed that customer orientation influenced customers' assessment of employees' service behaviors. In particular, customer orientation has to be more important for FLEs, who always respond to customers in their daily work in the service industry (e.g., the tourism and hospitality industry). Extant literature has insisted that customer orientation is a valuable resource enhancing psychological and work outcomes, such as commitment and performance, among FLEs [32]. In the long term, creating a customer-oriented organizational culture and retaining more customer-oriented FLEs can be a sustainable competitive advantage in the tourism and hospitality industry.

In this study, we expected that employee satisfaction resulting from sustainable HRM practices, including training, reward, and benefit, would positively affect employee customer orientation. Social exchange theory explains that employees who perceive that they have benefited from their organization are motivated to more actively engage with a reciprocal attitude or behavior [17]. Lee et al. [33] found that satisfied employees showed a higher level of customer orientation. We also predicted that, after meeting employees' own satisfaction, employees may display an enthusiastic pro-social disposition in their consideration of others, such as in customer orientation. Based on this discussion, we hypothesized that:

H2. Employee satisfaction is positively related to customer orientation.

\subsection{FLE-Supportive Context}

In the tourism and hospitality industry, the role of FLEs can determine the success of the organization. Specifically, FLEs such as front desk agents, porters, and waiting staff who frequently serve customers in their daily work are the face of organizations in the hotel industry. However, the recent growth and development of the service industry has provided customers with more options and higher expectations for their services and facilities [8]. Customers' complex and rushed service demands cause stress and anxiety for FLEs, which can lead to counterproductive behaviors, absenteeism, and turnover [9]. Even worse, intensive competition in the hotel industry has fueled the transfer of competent FLEs to competitors offering better opportunities and conditions. The voluntary turnover of customer-oriented FLEs would be a significant loss. In poor service conditions, how can the service organization improve FLEs' customer orientation to generate a sustainable competitive advantage? We tried to answer this question from the self-determination perspective. Self-determination theory emphasizes three essential human needs-namely, autonomy, relatedness, and competence needs-for internally motivating individuals [14]. In this study, we considered competence to be pre-trained and focused on autonomy and relatedness required for on-site interactions with customers. Thus, we suggested creating an FLE-supportive context with organizational empowerment and communication. In other words, we expected that organizational allowance for self-discretion and free communication would be a core facilitator for satisfying FLEs and encouraging them to 
immediately lead on-site service situations by themselves. From the view of social exchange theory, even though FLEs satisfied with sustainable HRM practices attempt to devote themselves to the organization, empowerment and communication at the organizational level should be provided as well in order to trigger their customer orientation.

\subsubsection{Moderating Role of Organizational Empowerment}

Satisfied FLEs would be willing to contribute to high-quality customer service as a form of reciprocation for their organization, whereas FLEs who perceive HRM practices to not be beneficial may be unlikely to adopt a proactive customer orientation. Thus, employee satisfaction would be an essential prerequisite for improving customer orientation. However, a, FLE-supportive context should be promoted to facilitate FLEs' customer orientation. FLEs are required to cope with customers' unexpected needs and wants. In such difficult situations, empowerment is the most helpful resource. The empowerment granted by the organization enables FLEs to have flexibility, discretion, free will, self-control, and self-care [34]. Previous literature has found that empowered service employees can effectively deal with customers or hardships and tend to better generate new ideas and constructive suggestion [35]. Spreitzer [36] regarded empowerment as a motivational construct and suggested four key characteristics: self-efficacy, self-determination, meaning, and impact on one's own job. At the organizational level, empowerment can provide employees with access to the necessary information and resources, various perspectives, and obligation and responsibility [34,37]. Thus, organizational empowerment enables satisfied FLEs to provide more customized services. However, when satisfied FLEs are committed to serving their customers, if they are not given autonomy or discretion, they are not able to respond promptly and appropriately to their demanding customers due to low flexibility. Based on this discussion, we hypothesized that:

H3. The positive relationship between employee satisfaction and customer orientation is stronger when organizational empowerment is high rather than low.

\subsubsection{Moderating Role of Organizational Communication}

Organizational communication can be another FLE-supportive context that enhances satisfied FLEs' customer orientation. Organizational communication includes various aspects in the eyes of FLEs, including the exchange of opinions with the service manager, constructive feedback from the service manager, smooth information sharing among service members, interdepartmental cooperation, voicing of opinions and expressing of difficulties to management, and an open communication organization climate. The communication of service standards, such as policies and practices, is crucial for service employees, as it provides a desirable guideline for customer service and reduces uncertainty and doubts by establishing what the employees can or cannot do and what attitudes or behaviors will be rewarded or punished [38,39]. Thus, service standards should be well communicated and understood by all FLEs. In addition, effective communication could help satisfied FLEs focus on higher customer satisfaction. Arasli et al. [40] discovered that constructive feedback of service managers facilitated FLEs' service innovate behavior through psychological safety and engagement in creative work. Although satisfied FLEs are motivated to devote themselves to their customer, it is quite difficult to completely resolve clumsy requests and complaints from customers through their own efforts because such troubles are contingent and require quicker solutions [41]. Knowledge sharing and organizational learning through open communication and cooperation at diverse levels, such as between service managers and members, can give confidence and belief to satisfied FLEs in their enthusiastic service orientation. However, the passion of satisfied FLEs may not lead to customer orientation in a context where FLEs are not obviously aware of service standards and remain unconvinced that they will get help from service members. Based on this discussion, we hypothesized that: 
H4. The positive relationship between employee satisfaction and customer orientation is stronger when organizational communication is high rather than low.

Figure 1 indicates our integrated research model.

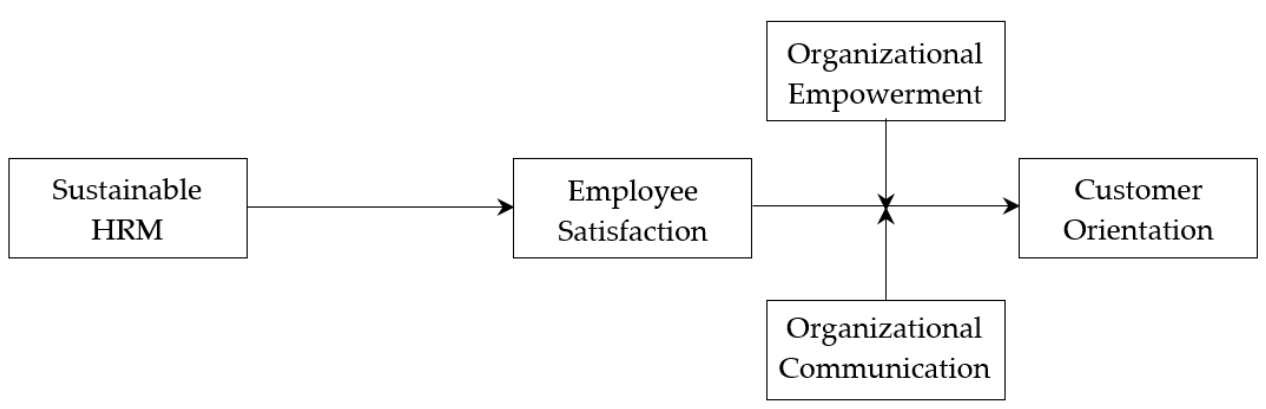

Figure 1. Research Model.

\section{Methods}

\subsection{Sample and Procedure}

We collected survey data from employees working for tourist, business, and luxury hotels in South Korea. The cover letter for the questionnaire explained the objective of the research and guaranteed confidentiality. Data were collected from May to June 2020. In total, 255 questionnaires were returned from the participants. However, 9 of the 255 questionnaires were dropped due to missing values and unfaithful responses; thus, 246 questionnaires were used for the final analysis. Among the participants, $480.4 \%$ were male, $60.2 \%$ were less than 35 years old, and $570.7 \%$ had less than three years of organizational tenure. Furthermore, $580.5 \%$ were entry-level workers, $550.7 \%$ had earned undergraduate degrees, and 750.6\% received an annual income less than 35 million won (cf. 1000 Korean won $=$ USD $0.90=$ CHF 0.80). Married employees accounted for $370.8 \%$. Finally, employees working for an organization with 50 to 100 employees accounted for $410.9 \%$.

\subsection{Measures}

All English scales were translated into Korean by three academicians using the backtranslation method in order to ensure accuracy of meaning [42]. We adapted most of the items for study variables for the research context and used a five-point Likert-type scale with scores ranging from strongly disagree (1) to strongly agree (5). Sustainable HRM, including training, reward, and benefit, was measured using a 15-item scale from Conduit and Mavondo [43]. The four items for training asked respondents about the programs helping service behavior, programs improving teamwork, programs for self-development, and about providing a sufficient number of training programs. Sample items included "Our hotel provides training programs that help perform a service." The six items for reward asked respondents about reflecting customer evaluation in compensation, compensation for service performance, compensation for employee excellence, compensation for constructive opinions, compensation for goal achievement, and promotion based on performance. Sample items included "Our hotel reflects customer evaluations in employees' compensation." The five items for benefit asked respondents about the offering of various benefits, pleasant working environments, convenient rest facilities, childcare support systems, and paid vacation systems. Sample items included "Our hotel offers employees various benefits." Cronbach's alphas were 0.86, 0.89, and 0.85, respectively. Employee satisfaction was measured using a five-item scale from Elci and Alpkan [44]. Those items asked respondents about overall job satisfaction, the sense of accomplishment at work, the sense of pride in work, satisfaction with an organizational system, and satisfaction with an organization. A sample item was "Overall, I am satisfied with my job". Cronbach's alpha was 0.85. Organizational empowerment was measured using a four-item scale from Matthews et al. [45]. Those items asked respondents about autonomy of decision making, discretion for problem solving, trusting employees' judgement, and respecting employees' creative thinking. A 
sample item was "Our hotel allows employees the autonomy of decision making when responding to customers". Cronbach's alpha was 0.83 . Organizational communication was measured using a five-item scale from Narver and Slater [40]. Those items asked respondents about smooth communication among employees, opinion exchange with supervisors, interdepartmental cooperation, open communication climates, and voicing of opinions or difficulties. A sample item was "In our hotel, there is a smooth communication among employees regarding customer service". Cronbach's alpha was 0.83 . Customer orientation was measured using a six-item scale from Narver and Slater [46]. Those items asked respondent about doing one's best, confidence in the best service, effort made to solve service problems, attempts to identify customer needs, customer-centered thinking, and recognizing the importance of customer satisfaction. A sample item was "I always do my best to satisfy customers." Cronbach's alpha was 0.84 . Control variables (i.e., gender, age, tenure, rank, annual income, education level, marital status, and organizational size) were included in the hierarchical multiple regression analyses to prevent potential exogenous effects.

\subsection{Confirmatory Factor Analysis}

To verify the discriminant validity among study variables, we conducted a confirmatory factor analysis. Prior to the analysis, we used item parcels for those variables in order to remedy the potential limitation of a hypothesized model with a large number of items in the small samples [47]. The results of the confirmatory factor analysis indicated that our hypothesized model, a 7-factor model, better fit the data than other alternative models (i.e., 5-factor to 1-factor models): $x^{2}(d f)=2110.63(83), \mathrm{CFI}=0.95, \mathrm{TLI}=0.93, \mathrm{RMSEA}=0.08$ (see Table 1). Thus, the findings demonstrate the independence among the variables in our hypothesized model.

Table 1. Comparison of measurement models.

\begin{tabular}{cccccccc}
\hline Model & $x^{2}$ & $d f$ & $\Delta x^{2}$ & $\Delta d f$ & CFI & TLI & RMSEA \\
\hline 7-factor model & 2110.63 & 83 & - & - & 0.95 & 0.93 & 0.08 \\
5-factor model & 3370.74 & 94 & $1260.11^{* *}$ & 11 & 0.90 & 0.87 & 0.10 \\
4-factor model & 3770.46 & 98 & $1650.83^{* *}$ & 15 & 0.88 & 0.86 & 0.11 \\
3-factor model & 4970.66 & 101 & $2860.03^{* *}$ & 18 & 0.84 & 0.81 & 0.13 \\
2-factor model & 5540.27 & 103 & $3420.64^{* *}$ & 20 & 0.82 & 0.79 & 0.14 \\
1-factor model & 7770.93 & 104 & $5660.30^{* *}$ & 21 & 0.73 & 0.69 & 0.16 \\
\hline
\end{tabular}

Note. $n=246 .{ }^{* *} p<0.01, \Delta x^{2}$ : The changes of Chi-square are against the seven-factor model, $\Delta d f:$ The changes of degrees of freedom are against the seven-factor model. CFI = comparative fit index; TLI = Tucker-Lewis Index; RMSEA = root mean square of error of approximation.

7-factor model: training, reward, benefit, satisfaction, empowerment, communication, orientation.

5-factor model: training + reward + benefit, satisfaction, empowerment, communication, orientation.

4-factor model: training + reward + benefit, satisfaction, empowerment + communication, orientation.

3-factor model: training + reward + benefit, satisfaction + empowerment + communication, orientation.

2-factor model: training + reward + benefit + satisfaction + empowerment + communication, orientation.

1-factor model: training + reward + benefit + satisfaction + empowerment + communication + orientation.

\subsection{Accessing Common Method Bias}

Our survey data were collected from the self-reported questionnaires of participants. Thus, we used two statistical tests to check the latent effects of same-source variance. Initially, we performed Harman's [48] single-factor test. The result of the exploratory factor analysis showed that the first factor accounted for only $140.57 \%$ of the total $670.39 \%$. To further confirm the same-source variance, we conducted a more rigorous confirmatory factor analysis. An unmeasured latent common method factor was added to our hypothesized model [49]. We compared the model fit indices before and after adding the common method factor. As a result, all factor loadings of items on the study variables were significant even with the addition of the common method factor and the model with the additional factor showed better fit indices than the model without the additional factor: $x^{2}(d f)=1950.07(82)$, CFI $=0.96$, TLI $=0.93$, RMSEA $=0.07$. Thus, the inclusion of the common method factor increased the overall model fit indices while the variance explained 
by this factor was only $150.21 \%$ of the total variance. Williams, Cote, and Buckly [50] suggested that the variance explained by the common method factor should be lower than $25 \%$. Thus, we concluded that common method bias was not a concern in this study.

\section{Results}

\subsection{Correlation}

Table 2 indicates the means, standard deviations, and correlations among the study variables in our hypothesized model.

Table 2. Descriptive statistics and correlations.

\begin{tabular}{|c|c|c|c|c|c|c|c|c|c|c|c|c|c|c|c|c|}
\hline Variable & Mean & SD & 1 & 2 & 3 & 4 & 5 & 6 & 7 & 8 & 9 & 10 & 11 & 12 & 13 & 14 \\
\hline 1. Gender & 0.48 & 0.50 & & & & & & & & & & & & & & \\
\hline 2. Age & 20.19 & 0.96 & 0.07 & & & & & & & & & & & & & \\
\hline 3. Tenure & 10.90 & 10.24 & $0.20^{*}$ & $0.34 * *$ & & & & & & & & & & & & \\
\hline 4. Rank & 20.36 & 10.03 & 0.03 & 0.15 & $0.50^{*}$ & & & & & & & & & & & \\
\hline 5. Annual Income & 20.56 & 10.52 & $0.24 *$ & $0.21^{*}$ & $0.63 *$ & $0.51 *$ & & & & & & & & & & \\
\hline 6. Education Level & 20.56 & 0.79 & -0.03 & -0.18 * & 0.13 & $0.28 *$ & $0.27 *$ & & & & & & & & & \\
\hline 7. Marital Status & 0.37 & 0.48 & -0.06 & $0.41 *$ & 0.35 * & 0.36 * & $0.23 *$ & 0.01 & & & & & & & & \\
\hline 8. Organization Size & 10.97 & 0.76 & 0.03 & $\begin{array}{l}0.09 \\
0.09\end{array}$ & 0.13 & $0.23 *$ & 0.27 * & 0.10 & 0.10 & & & & & & & \\
\hline 9. Training & 30.01 & 0.93 & 0.12 & 0.09 & 0.01 & 0.05 & 0.12 & 0.00 & 0.02 & 0.02 & & & & & & \\
\hline 10. Reward & 20.84 & 0.89 & 0.11 & 0.10 & 0.08 & 0.14 & 0.15 & 0.12 & 0.06 & 0.05 & 0.68 * & & & & & \\
\hline 11. Benefit & 30.15 & 0.90 & 0.05 & 0.08 & 0.03 & 0.15 & 0.15 & 0.08 & 0.05 & 0.12 & 0.65 * & 0.71 * & & & & \\
\hline 12. Satisfaction & 30.11 & 0.85 & 0.07 & 0.13 & 0.06 & 0.09 & $0.20 *$ & 0.03 & 0.08 & 0.00 & 0.74 * & $0.72 *$ & $0.76^{*}$ & & & \\
\hline 13. Empowerment & 30.17 & 0.80 & 0.06 & 0.12 & 0.07 & 0.03 & 0.09 & -0.07 & 0.05 & 0.00 & 0.50 * & 0.51 * & 0.43 * & $0.57^{*}$ & & \\
\hline 14. Communication & 30.30 & 0.71 & 0.13 & 0.11 & 0.05 & 0.00 & 0.12 & -0.06 & 0.05 & -0.04 & 0.55 * & 0.52 * & 0.44 * & $0.62 *$ & $0.62 *$ & \\
\hline 15. Orientation & 30.84 & 0.61 & $0.19 *$ & 0.15 & 0.00 & -0.03 & 0.08 & -0.20 * & 0.03 & -0.00 & 0.22 * & 0.17 * & 0.18 * & 0.27 * & 0.31 * & $0.41^{* *}$ \\
\hline
\end{tabular}

\subsection{Hypothesis Testing}

To test the hypotheses, we conducted a series of hierarchical multiple regression analyses (see Table 3). The effects of control variables alone are presented in Model 1 and Model 3. In Model 2, training, reward, and benefit, three facets of sustainable HRM, were all positively related to employee satisfaction $(\beta=0.32, p<0.001 ; \beta=0.22, p<0.001$; $\beta=0.40, p<0.001$ ). Thus, H1a, H1b, and H1c were supported. In Model 5, employee satisfaction was positively related to customer orientation, even controlling for training, reward, and benefit $(\beta=0.27, p<0.05)$. Thus, $\mathrm{H} 2$ was supported. We added the interaction terms generated by multiplying mean-centering values of two variables in order to test the moderating effects of organizational empowerment and communication. In Model 6 , the positive relationship between employee satisfaction and customer orientation was stronger when organizational empowerment was high $(\beta=0.25, p<0.001)$. In addition, in Model 7, the positive relationship between employee satisfaction and customer orientation was stronger when organizational communication was high $(\beta=0.17, p<0.01)$. Thus, $\mathrm{H} 3$ and $\mathrm{H} 4$ were supported.

To further examine the mediating role of employee satisfaction, we carried out a bootstrapping test of the indirect effects. We checked the estimates for indirect effect, standard error, and bias-corrected $95 \%$ confidence interval (CI) using 10,000 bootstrapped samples [51]. If the CI for the indirect effect estimate does not include zero, the effect of the mediator variable can be determined to be significant [52]. Table 4 indicates the results. The CIs for the estimates of all three facets of sustainable HRM for customer orientation through employee satisfaction did not include zero: training $(0.03,0.20)$, reward $(0.04,0.22)$, and benefit $(0.04,0.25)$. Thus, we proved the statistical significance of employee satisfaction, as a mediator, between sustainable HRM and customer orientation. 
Table 3. Results of hierarchical multiple regression.

\begin{tabular}{|c|c|c|c|c|c|c|c|}
\hline \multirow{2}{*}{ Variable } & \multicolumn{2}{|c|}{$\begin{array}{c}\text { Employee } \\
\text { Satisfaction }\end{array}$} & \multicolumn{5}{|c|}{$\begin{array}{c}\text { Customer } \\
\text { Orientation }\end{array}$} \\
\hline & M 1 & M 2 & M 3 & M 4 & M 5 & M 6 & M 7 \\
\hline \multicolumn{8}{|l|}{ Control } \\
\hline Gender & 0.04 & -0.04 & 0.17 & 0.15 & 0.16 & 0.12 & 0.13 \\
\hline Age & 0.13 & 0.03 & 0.12 & 0.09 & 0.09 & 0.07 & 0.07 \\
\hline Tenure & 0.03 & -0.06 & -0.03 & -0.05 & -0.03 & 0.03 & 0.02 \\
\hline Rank & -0.18 & -0.03 & -0.15 & -0.12 & -0.11 & -0.11 & -0.10 \\
\hline Annual Income & $0.27 *$ & $0.15^{*}$ & 0.19 & 0.16 & 0.12 & 0.11 & 0.10 \\
\hline Education Level & 0.01 & -0.04 & -0.19 * & -0.20 * & -0.19 * & -0.19 * & -0.16 \\
\hline Marital Status & 0.03 & 0.03 & 0.02 & 0.02 & 0.01 & 0.01 & 0.01 \\
\hline Organizational Size & -0.07 & -0.08 & -0.03 & -0.03 & -0.01 & 0.03 & 0.02 \\
\hline \multicolumn{8}{|l|}{ Independent } \\
\hline Training & & $0.32 * *$ & & 0.10 & 0.02 & -0.03 & -0.02 \\
\hline Reward & & $0.22 * *$ & & 0.05 & -0.02 & -0.11 & -0.11 \\
\hline Benefit & & $0.40 * *$ & & 0.07 & -0.03 & 0.01 & 0.04 \\
\hline \multicolumn{8}{|l|}{ Mediator } \\
\hline Employee Satisfaction (S) & & & & & 0.27 & 0.20 & 0.08 \\
\hline \multicolumn{8}{|l|}{ Moderator } \\
\hline Organizational Empowerment (E) & & & & & & $0.27^{* *}$ & \\
\hline Organizational Communication (C) & & & & & & & $0.36^{* *}$ \\
\hline \multicolumn{8}{|l|}{ Interaction } \\
\hline $\mathrm{S} \times \mathrm{E}$ & & & & & & $0.25^{* *}$ & \\
\hline $\mathrm{S} \times \mathrm{C}$ & & & & & & & 0.17 * \\
\hline$R^{2}$ & 0.07 & $0.72 * *$ & $0.11 *$ & $0.14^{* *}$ & $0.16^{* *}$ & $0.25^{* *}$ & $0.27^{* *}$ \\
\hline$\Delta R^{2}$ & 0.07 & $0.65^{* *}$ & $0.11 *$ & 0.03 & 0.02 & $0.09 * *$ & $0.11^{* *}$ \\
\hline
\end{tabular}

Note. $n=246 .{ }^{*} p<0.05,{ }^{* *} p<0.01,^{* * *} p<0.001$ (standardized regression coefficients are reported).

Table 4. Bootstrapping test of indirect effects.

\begin{tabular}{lcccc}
\hline & & & \multicolumn{2}{c}{ Bias-Corrected } \\
Indirect Path & $\boldsymbol{b}$ & S.E. & \multicolumn{2}{c}{ CI } \\
\cline { 3 - 5 } & & & Lower & Upper \\
\hline Training $\rightarrow$ employee satisfaction $\rightarrow$ customer orientation & 0.12 & 0.04 & 0.03 & 0.20 \\
Reward $\rightarrow$ employee satisfaction $\rightarrow$ customer orientation & 0.13 & 0.05 & 0.04 & 0.22 \\
Benefit $\rightarrow$ employee satisfaction $\rightarrow$ customer orientation & 0.14 & 0.06 & 0.04 & 0.25 \\
\hline
\end{tabular}

Note. $n=246.10,000$ bootstrap resamples, $\mathrm{CI}=$ confidence interval.

To shed light on the moderating roles of organizational empowerment and communication between employee satisfaction and customer orientation, we plotted the simple slopes for the two interaction terms. First, we divided the samples into high and low groups each for organizational empowerment and communication by one standard deviation above and below the mean value [53]. We then performed the simple slope test to check the significance of the two slopes by group [54]. Figure 2 indicates the results. In the group that perceived high organizational empowerment, employee satisfaction and customer orientation showed a significantly positive relationship $(b=0.29$, S.E. $=0.09$, $t=30.16, p<0.01)$; however, there was no significant relationship for the group that perceived low organizational empowerment $(b=-0.02$, S.E. $=0.08, t=-0.24, p<0.75)$. In the group that perceived high organizational communication, employee satisfaction and customer orientation showed a significantly positive relationship $(b=0.17, S . E .=0.08$, $t=10.92, p<0.05)$; however, there was no significant relationship for the group that perceived low organizational communication $(b=-0.06$, S.E. $=0.09, t=-0.61, p<0.54)$. Thus, it can be understood that employee satisfaction is positively related to customer orientation only when organizational empowerment or communication is highly perceived. 


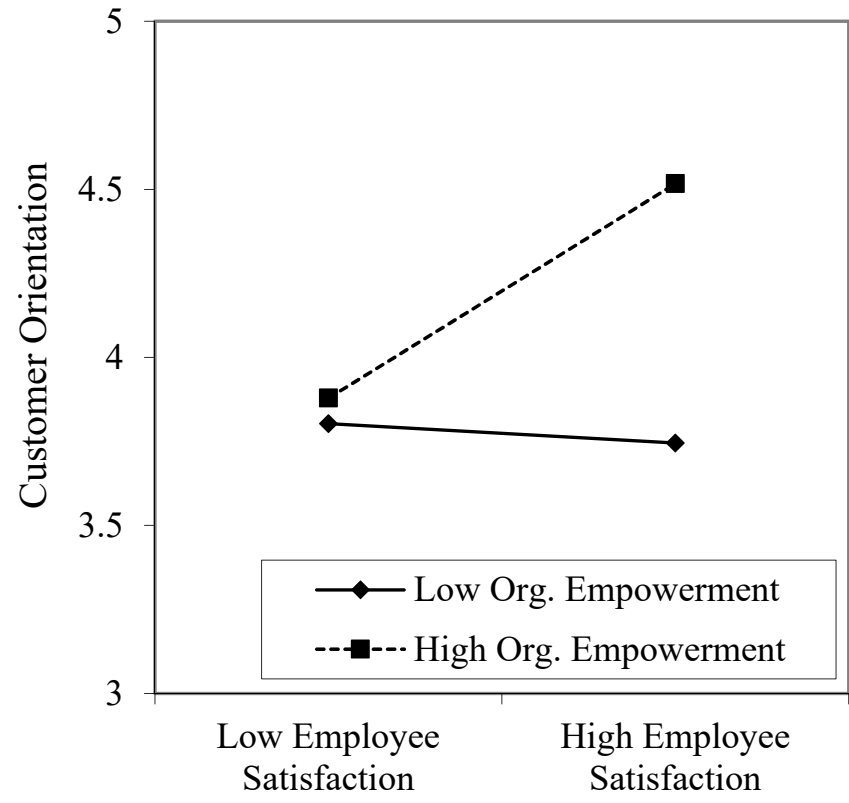

(a)

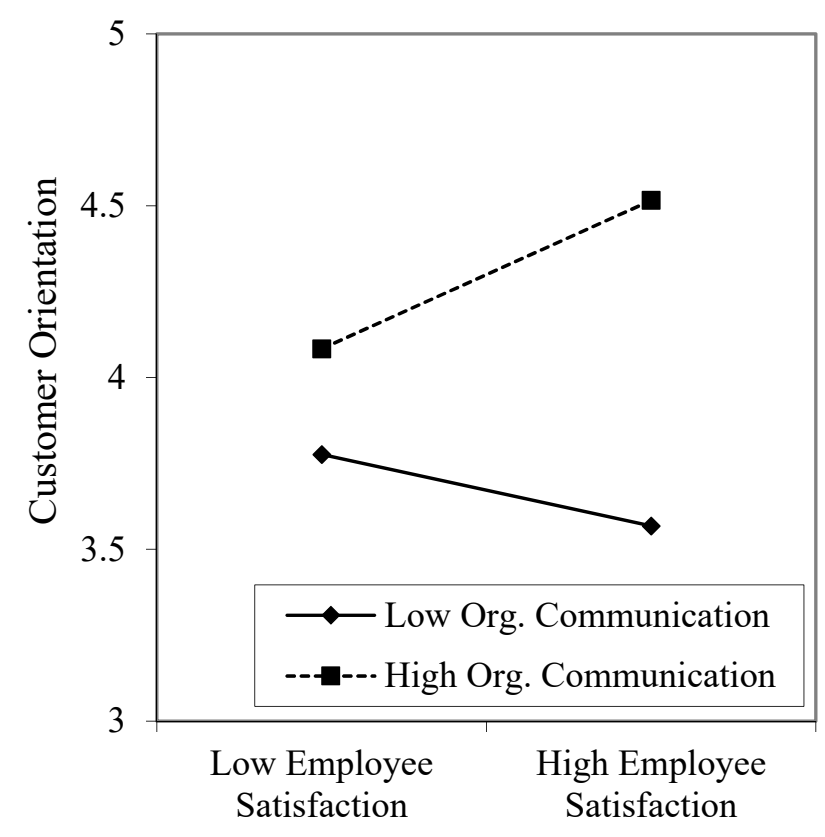

(b)

Figure 2. Moderating effects of (a) organizational empowerment and (b) organizational communication in the relationship between employee satisfaction and customer orientation.

\subsection{Conditional Indirect Effect Analysis}

To improve the robustness of the results presented thus far, we conducted a conditional indirect effect analysis. We checked the estimates for indirect effect, standard error, and biascorrected 95\% CI using 10,000 bootstrapped samples according to different conditions [55], high or low organizational empowerment, and communication. Table 5 summarizes the results. The CIs for the estimates of all three facets of sustainable HRM for customer orientation through employee satisfaction did not include zero only when organizational empowerment was highly perceived: training $(0.07,0.26)$, reward $(0.09,0.30)$, and benefit $(0.05,0.29)$. Similarly, the CIs for the estimates of all three facets of sustainable HRM for customer orientation through employee satisfaction did not include zero only when organizational communication was highly perceived: training $(0.01,0.20)$, reward $(0.02$, $0.24)$, and benefit $(0.01,0.19)$. These findings strongly verify the mediating role of employee satisfaction and the moderating roles of organizational empowerment and communication between sustainable HRM and customer orientation in an integrated model.

Table 5. Summary of conditional indirect effects.

\begin{tabular}{|c|c|c|c|c|}
\hline Indirect Path & \multicolumn{2}{|c|}{ Condition } & $b$ & $95 \%$ CI \\
\hline Training $\rightarrow$ employee satisfaction $\rightarrow$ customer orientation & & $\begin{array}{l}\mathrm{H} \\
\mathrm{L}\end{array}$ & $\begin{array}{c}0.17 \\
-0.01\end{array}$ & $\begin{array}{c}0.07,0.26 \\
-0.11,0.08\end{array}$ \\
\hline Reward $\rightarrow$ employee satisfaction $\rightarrow$ customer orientation & $\begin{array}{l}\text { Organizational } \\
\text { empowerment }\end{array}$ & $\begin{array}{l}\mathrm{H} \\
\mathrm{L}\end{array}$ & $\begin{array}{l}0.19 \\
0.00\end{array}$ & $\begin{array}{c}0.09,0.30 \\
-0.10,0.10\end{array}$ \\
\hline Benefit $\rightarrow$ employee satisfaction $\rightarrow$ customer orientation & & $\begin{array}{l}\mathrm{H} \\
\mathrm{L}\end{array}$ & $\begin{array}{c}0.17 \\
-0.02\end{array}$ & $\begin{array}{c}0.05,0.29 \\
-0.14,0.10\end{array}$ \\
\hline Training $\rightarrow$ employee satisfaction $\rightarrow$ customer orientation & & $\begin{array}{l}\mathrm{H} \\
\mathrm{L}\end{array}$ & $\begin{array}{c}0.10 \\
-0.04\end{array}$ & $\begin{array}{c}0.01,0.20 \\
-0.14,0.05\end{array}$ \\
\hline Reward $\rightarrow$ employee satisfaction $\rightarrow$ customer orientation & $\begin{array}{l}\text { Organizational } \\
\text { communication }\end{array}$ & $\begin{array}{l}\mathrm{H} \\
\mathrm{L}\end{array}$ & $\begin{array}{c}0.13 \\
-0.03\end{array}$ & $\begin{array}{c}0.02,0.24 \\
-0.13,0.06\end{array}$ \\
\hline Benefit $\rightarrow$ employee satisfaction $\rightarrow$ customer orientation & & $\begin{array}{l}\mathrm{H} \\
\mathrm{L}\end{array}$ & $\begin{array}{c}0.10 \\
-0.06\end{array}$ & $\begin{array}{c}0.01,0.19 \\
-0.19,0.06\end{array}$ \\
\hline
\end{tabular}




\section{Discussion}

The present study examined the relationship between sustainable HRM practices and FLEs' customer orientation. Furthermore, we focused on the mediating role of employee satisfaction, as a psychological mechanism, and the moderating roles of organizational empowerment and organizational communication as FLE-supportive contexts. The results of this study are summarized as follows. All three facets of sustainable HRM practices (i.e., training, reward, and benefit) were positively and strongly related to FLEs' satisfaction. FLEs' satisfaction was also positively related to their customer orientation. In this study, there was no significantly direct relationship between the three facets of the sustainable HRM practices and FLEs' customer orientation. In addition, the results of bootstrapping tests of indirect effects supported the hypotheses concerning the significant mediating roles of employee satisfaction between the three facets of sustainable HRM practices and FLEs' customer orientation [51,52]. Furthermore, both the organizational empowerment and organizational communication significantly moderated the relationship between FLEs' satisfaction and their customer orientation. More specifically, FLEs' satisfaction and their customer orientation showed a positive relationship only for the group that perceived high organizational empowerment or communication. In contrast, the relationship was not significant for the group that perceived low organizational empowerment or communication $[53,54]$. In addition, the results of conditional indirect effect analyses indicated that all three facets of the sustainable HRM practices were positively related to FLEs' customer orientation through their satisfaction under the condition of high organizational empowerment or communication [55]. These findings support all the hypotheses from our theoretical framework.

\subsection{Theoretical and Practical Implications}

The research findings of this study provide important theoretical and practical implications. First, we confirmed the distinct mediating role of employee satisfaction between the sustainable HRM practices and customer orientation. From the perspective of internal marketing [19], our findings proved that the satisfaction of internal customers led to their customer orientation increasing the satisfaction of external customers [3,5]. Indeed, employees felt that they benefited from the organization and tended to enthusiastically serve their customers as an act of reciprocation with their organization, as described by social exchange theory [17]. More importantly, this study approached the relationship between HRM practices and employee satisfaction with a theoretical lens emphasizing sustainability. In other words, although various traditional HRM practices may satisfy employees, we focused only on sustainable HRM practices (i.e., training, reward, and benefit). The reason is that these are beneficial to employees' self-development and well-being as well as the organization's sustainable competitive advantage [14,15]. Thus, one of the major contributions of this study is verification of the positive effects of three facets of sustainable HRM practices on employee satisfaction. The current study focused on hotel FLEs in the tourism and hospitality industry. As the industry has been rapidly developing and growing worldwide, FLEs have faced more difficulties from customers' unexpected demands and complaints $[8,41]$. Nevertheless, research on FLEs' customer orientation based on internal marketing in Asian contexts is quite limited [8]. Hotel management should sincerely consider ways to reduce FLEs' stress and improve their customer orientation. Enhancing FLEs' satisfaction by actively utilizing sustainable HRM practices may be a solution for their stress and customer orientation.

Second, we emphasized the importance of an FLE-supportive context for allowing organizational empowerment or organizational communication to FLEs. FLEs are themselves the employees who should promptly and properly deal with customers' complex, multiple needs and wants at the service encounter on a daily basis. Even if FLEs obtain satisfaction from sustainable HRM practices, they may not have a desirable customer orientation unless the context providing customized services is given to them. However, extant internal marketing literature has somewhat overlooked the significance of the ser- 
vice context in facilitating FLEs' positive attitudes or behaviors. Previous studies have mainly investigated the separate influence of HRM practices on employee satisfaction or outcomes $[1,8,22]$. In this study, we argued that FLEs should be given discretion for making decisions and engaging in helpful information exchanges in on-site service situations based on self-determination theory [18]. The research findings also demonstrated that the positive relationship between FLEs' satisfaction and their customer orientation is statistically significant only when they perceive high organizational empowerment or communication. Our findings entail practical implications, namely that effective empowerment and communication in service organizations are quite important to promote the positive spillover of FLEs' satisfaction on their customer-oriented behavior. Drawing upon these lessons, organizations should strive to continually identify the discretionary actions required for better customer service and update the scope of appropriate empowerment. In terms of organizational communication, leaders or managers should work out a way to consistently seek FLEs' opinions so that they can feel that the delegation of authority is actually useful. Using effective empowerment and communication, service organizations can succeed in establishing a supportive context in which FLEs can serve their customers in timely and sustainable manners. Another major contribution of this study is that the results suggest a new perspective for internal marketing researchers by shedding light on the importance of the service context. Management and practitioners in the tourism and hospitality industry, including the hotel industry, need to be aware of this. Even if service organizations satisfy their FLEs through sustainable HRM practices involving substantial efforts and investments, this may not improve customer orientation if organizations do not create an atmosphere of empowerment and open communication. What FLEs really need is self-determination in their interactions with customers.

\subsection{Limitations and Future Research Directions}

The limitations of this study imply the need for future research directions. First, this study had a potential common method bias due to collecting survey data from one subject. Although we checked that same-source variance was not a concern through two methodological remedies [48,49], future research should consider multiple sources to increase the reliability of the results. Second, we decided to adopt three facets-training, reward, and benefit—as sustainable HRM practices in the present study. However, sustainable HRM is a new concept characterized by regenerating and developing social, economic, and human resources $[14,15]$ and has various potentials in its application. Although we used the three facets for the theoretical framework based on our own rationale, future researchers could consider other facets according to their study objectives. Third, the current study focused on FLEs' customer orientation as an important outcome variable because this variable is one of the most influential antecedents for high-quality service to customers and customer satisfaction and retention [5]. Future studies could investigate other outcome variables from the perspective of internal marketing. They could focus on more objective variables; for example, researchers might measure customers' appraisal of FLE service or an organization's actual revenues or reputation compared to competitors in the same industry. Finally, we emphasized the importance of FLE-supportive contexts, such as organizational empowerment and communication. This may be a new perspective in internal marketing research. FLEs are quite different from office or production employees. It is recommended that future studies examine the diverse contexts in which the satisfaction of FLEs can be linked to their positive attitude or behavior at the service encounter.

Author Contributions: Conceptualization, Y.C. (Youngsam Cho) and Y.C. (Yongduk Choi); methodology, Y.C. (Youngsam Cho) and Y.C. (Yongduk Choi); formal analysis, Y.C. (Youngsam Cho) and Y.C. (Yongduk Choi); writing — original draft preparation, Y.C. (Youngsam Cho) and Y.C. (Yongduk Choi); writing-review and editing, Y.C. (Youngsam Cho) and Y.C. (Yongduk Choi); project administration, Y.C. (Youngsam Cho). All authors have read and agreed to the published version of the manuscript.

Funding: This research received no external funding. 
Institutional Review Board Statement: Not applicable.

Informed Consent Statement: Not applicable.

Data Availability Statement: Not applicable.

Conflicts of Interest: The authors declare no conflict of interest.

\section{References}

1. Marques, C.P.; Leal, C.T.; Marques, C.S.; Cabral, B.T. Internal marketing and job satisfaction in hotels in Via Costeira, Natal, Brazil. Tour. Manag. Stud. 2018, 14, 36-42. [CrossRef]

2. Coelho, F.J.; Evanschitzky, H.; Sousa, C.M.; Olya, H.; Taheri, B. Control mechanisms, management orientations, and the creativity of service employees: Symmetric and asymmetric modeling. J. Bus. Res. 2020. [CrossRef]

3. Stock, R.M. Understanding the relationship between frontline employee boreout and customer orientation. J. Bus. Res. 2016, 69, 4259-4268. [CrossRef]

4. Baek, U.; Olya, H.; Lee, S.K. Effects of individual resources and team-member exchange on service quality. Serv. Ind. J. 2018, 38, 584-606. [CrossRef]

5. Harter, J.K.; Schmidt, F.L.; Hayes, T.L. Business-unit-level relationship between employee satisfaction, employee engagement, and business outcomes: A meta-analysis. J. Appl. Psychol. 2002, 87, 268-279. [CrossRef] [PubMed]

6. Rucci, A.J.; Kirn, S.P.; Quinn, R.T. The employee-customer-profit chain at Sears. Harv. Bus. Rev. 1998, 76, 82-98.

7. Olya, H.; Taheri, B.; Farmaki, A.; Gannon, M.J. Modelling perceived service quality and turnover intentions in gender-segregated environments. Int. J. Consum. Stud. 2021, 1-18. [CrossRef]

8. Park, J.H.; Tran, T.B.H. Internal marketing, employee customer-oriented behaviors, and customer behavioral responses. Psychol. Mark. 2018, 35, 412-426. [CrossRef]

9. Schwepker, C.H., Jr. Customer-oriented selling: A review, extension, and directions for future research. J. Pers. Sell. Sales. Manag. 2003, 23, 151-171.

10. Skaer, M. Words of advice: Take care of those salespeople. Air. Cond. Heat. Cond. Heat. Refriger. News. 2006, $20,50$.

11. Uduji, J.I. Nagging problem of the plateaued salesperson: A meta-analysis. Sustain. Hum. Dev. Rev. 2009, 1, 13-23.

12. Heskett, J.L.; Jones, T.O.; Loveman, G.W.; Sasser, W.E., Jr.; Schlesinger, L.A. Putting the service-profit chain to work. Harv. Bus. Rev. 1994, 72, 164-174.

13. Ehnert, I.; Parsa, S.; Roper, I.; Wagner, M.; Muller-Camen, M. Reporting on sustainability and HRM: A comparative study of sustainability reporting practices by the world's largest companies. Int. J. Hum. Resour. Manag. 2016, 27, 88-108. [CrossRef]

14. Kramar, R. Beyond strategic human resource management: Is sustainable human resource management the next approach? Int. J. Hum. Resour. Manag. 2014, 25, 1069-1089. [CrossRef]

15. Hong, G.; Kim, E. How to attract talented expatriates: The key role of sustainable HRM. Sustainability 2019, 11, 5373. [CrossRef]

16. Mariappanadar, S. Do HRM systems impose restrictions on employee quality of life? Evidence from a sustainable HRM perspective. J. Bus. Res. 2020, 118, 38-48. [CrossRef]

17. Blau, P. Exchange and Power in Social Life; Wiley: New York, NY, USA, 1964.

18. Deci, E.L.; Ryan, R.M. The "what" and "why" of goal pursuits: Human needs and the self-determination of behavior. Psychol. Inq. 2000, 11, 227-268. [CrossRef]

19. Berry, L.L. The Employee as Customer. J. Retail. Banks. 1981, 3, 33-40.

20. Grönroos, C. Service Management and Marketing; Lexington Books: Lexington, MA, USA, 1990; Volume 94.

21. Rafiq, M.; Ahmed, P.K. Advances in the internal marketing concept: Definition, synthesis and extension. J. Serv. Mark. 2000, 14, 449-462. [CrossRef]

22. Nart, S.; Sututemiz, N.; Nart, S.; Karatepe, O.M. Internal marketing practices, genuine emotions and their effects on hotel employees' customer-oriented behaviors. J. Hum. Resour. Hosp. Tour. 2019, 18, 47-70. [CrossRef]

23. Marescaux, E.; De Winne, S.; Sels, L. HR practices and HRM outcomes: The role of basic need satisfaction. Pers. Rev. 2013, 42, 4-27. [CrossRef]

24. Suazo, M.M.; Martínez, P.G.; Sandoval, R. Creating psychological and legal contracts through human resource practices: A signaling theory perspective. Hum. Resour. Manage. Rev. 2009, 19, 154-166. [CrossRef]

25. Adams, J.S. Inequity in social exchange. In Advances in Experimental Social Psychology; Berkowitz, L., Ed.; Academic Press: New York, NY, USA, 1965; Volume 2, pp. 267-299.

26. Porter, L.W.; Lawler, E.E. Managerial Attitudes and Performance; Irwin-Dorsey: Homewood, CA, USA, 1968.

27. Arasli, H.; Nergiz, A.; Yesiltas, M.; Gunay, T. Human resource management practices and service provider commitment of green hotel service providers: Mediating role of resilience and work engagement. Sustainability 2020, 12, 9187. [CrossRef]

28. Shaw, J.D.; Delery, J.E.; Jenkins, G.D., Jr.; Gupta, N. An organization-level analysis of voluntary and involuntary turnover. Acad. Manag. J. 1998, 41, 511-525.

29. Gomez-Mejia, L.R.; Balkin, D.B.; Cardy, R.L.; Carson, K.P. Managing Human Resources; Pearson/Prentice Hall: Upper Saddle River, NJ, USA, 2007.

30. Saxe, R.; Weitz, B.A. The SOCO scale: A measure of the customer orientation of salespeople. J. Mark. Res. 1982, $19,343-351$. [CrossRef] 
31. Brady, M.K.; Cronin, J.J., Jr. Customer orientation: Effects on customer service perceptions and outcome behaviors. J. Serv. Res. 2001, 3, 241-251. [CrossRef]

32. Zablah, A.R.; Franke, G.R.; Brown, T.J.; Bartholomew, D.E. How and when does customer orientation influence frontline employee job outcomes? A meta-analytic evaluation. J. Mark. 2012, 76, 21-40. [CrossRef]

33. Lee, C.K.; Song, H.J.; Lee, H.M.; Lee, S.; Bernhard, B.J. The impact of CSR on casino employees' organizational trust, job satisfaction, and customer orientation: An empirical examination of responsible gambling strategies. Int. J. Hosp. Manag. 2013, 33, 406-415. [CrossRef]

34. Khalili, H.; Sameti, A.; Sheybani, H. A study on the effect of empowerment on customer orientation of employees. Glob. Bus. Rev. 2016, 17, 38-50. [CrossRef]

35. Fernandez, S.; Moldogaziev, T. Empowering public sector employees to improve performance: Does it work? Amer. Rev. Public. Adm. 2011, 41, 23-47. [CrossRef]

36. Spreitzer, G.M. Psychological empowerment in the workplace: Dimensions, measurement, and validation. Acad. Manag. J. 1995, 38, 1442-1465.

37. Pham Thi Phuong, L.; Ahn, Y.J. Service climate and empowerment for customer service quality among Vietnamese employees at restaurants. Sustainability 2021, 13, 1172. [CrossRef]

38. Amenumey, E.K.; Lockwood, A. Psychological climate and psychological empowerment: An exploration in a luxury UK hotel group. Tour. Hosp. Res. 2008, 8, 265-281. [CrossRef]

39. Ro, H.; Chen, P.J. Empowerment in hospitality organizations: Customer orientation and organizational support. Int. J. Hosp. Manag. 2011, 30, 422-428. [CrossRef]

40. Arasli, H.; Arici, H.E.; Kole, E. Constructive leadership and employee innovative behaviors: A serial mediation model. Sustainability 2020, 12, 2592. [CrossRef]

41. Aryee, S.; Kim, T.Y.; Zhou, Q.; Ryu, S. Customer service at altitude: Effects of empowering leadership. Int. J. Contemp. Hosp. Manag. 2019, 31, 3722-3741. [CrossRef]

42. Brislin, R.W. Translation and content analysis of oral and written materials. In Handbook of Cross-Cultural Psychology; Triandis, H.C., Berry, J.W., Eds.; Allyn and Bacon: Boston, MA, USA, 1980; Volume 2, pp. 389-444.

43. Conduit, J.; Mavondo, F.T. How critical is internal customer orientation to market orientation? J. Bus. Res. 2001, 51, 11-24. [CrossRef]

44. Elçi, M.; Alpkan, L. The impact of perceived organizational ethical climate on work satisfaction. J. Bus. Ethics 2009, 84, 297-311. [CrossRef]

45. Matthews, R.A.; Diaz, W.M.; Cole, S.G. The organizational empowerment scale. Pers. Rev. 2003, 32, 297-318. [CrossRef]

46. Narver, J.C.; Slater, S.F. The effect of a market orientation on business profitability. J. Mark. 1990, 54, 20-35. [CrossRef]

47. Little, T.D.; Cunningham, W.A.; Shahar, G.; Widaman, K.F. To parcel or not to parcel: Exploring the question, weighing the merits. Struct. Equ. Modeling 2002, 9, 151-173. [CrossRef]

48. Harman, D. A single factor test of common method variance. J. Psychol. 1967, 35, 359-378.

49. Podsakoff, P.M.; MacKenzie, S.B.; Podsakoff, N.P. Sources of method bias in social science research and recommendations on how to control it. Annu. Rev. Psychol. 2012, 63, 539-569. [CrossRef] [PubMed]

50. Williams, L.J.; Cote, J.A.; Buckley, M.R. Lack of method variance in self-reported affect and perceptions at work: Reality or artifact? J. Appl. Psychol. 1989, 74, 462-468. [CrossRef]

51. Hayes, A.F. Introduction to Mediation, Moderation, and Conditional Process Analysis a Regression-Based Approach; The Guilford Press: New York, NY, USA, 2013.

52. Preacher, K.J.; Hayes, A.F. Asymptotic and resampling strategies for assessing and comparing indirect effects in multiple mediator models. Behav. Res. Methods 2008, 40, 879-891. [CrossRef] [PubMed]

53. Aiken, L.S.; West, S.G. Multiple Regression: Testing and Interpreting Interactions; Sage: Newburry Park, CA, USA, 1991.

54. Cohen, J.; Cohen, P.; West, S.G.; Aiken, L.S. Applied Multiple Regression/Correlation Analysis for the Behavioral Sciences, 3rd ed.; Erlbaum: Mahwah, NJ, USA, 2003.

55. Preacher, K.J.; Rucker, D.D.; Hayes, A.F. Addressing moderated mediation hypotheses: Theory, methods, and prescriptions. Multivar. Behav. Res. 2007, 42, 185-227. [CrossRef] [PubMed] 